\title{
THE SHEPHERD-LEADER MOTIF AS A PASTORAL MODEL FOR A GLOBALIZING CHURCH
}

\author{
NATHAN H. GUNTER*
}

Southern Baptist Theological Seminary

\begin{abstract}
The simultaneous globalization and demographic shift of the Church to the Global South has produced an unprecedented climate for theological work. Pastors and theologians are confronted with the task of developing theological systems that are faithful to the authoritative standard of Scripture, tailored to the increasingly complex needs of their local contexts, and sensitive to the ongoing dialogue of other leaders around the globe. In light of the increasing cross-cultural dialogue among scholars and pastors within a globalized church and a corresponding desire to encourage greater 'diasporadic consciousness' therein, this article presents the biblical-theological shepherd-leader motif as a primary metaphor for understanding the distinct nature and role of pastoral leadership. This article presents shepherd leadership as a robust metaphor of pastoral leadership by reviewing Scripture's use of the metaphor and recent significant works on the subject. In the second section of the article, I propose a model profile of the biblical shepherd-leader based upon the insights of the biblical-theological review.
\end{abstract}

KEYWORDS: pastoral leadership, shepherd leadership, globalization, cross-cultural theology

\section{Introduction}

'The greatest single challenge that has come upon the Christian faith during the last century has been the demographic shift in its focus away from its traditional centres in Europe and North America' (Parratt 2004: 1). Indeed, this shift is well-documented and is carrying with it unprecedented changes in the way theologians and pastors understand theological themes in the faith and practice of believers gathering in diverse contexts across the globe. The Center for the Study of Global Christianity reports, 'The twentieth century experienced the great shift of Christianity to the global South, a trend that will continue into the future' (2016: 7). This shift is clearly evident, for example, in Africa, where the Christian population is expected to increase from 142 million in 1970 to more than 650 million African Christians by the year 2020 (Pew Research Center 2016: 2). This is not the first

* $\quad$ NATHAN H. GUNTER (EdD 2016, Southern Baptist Theological Seminary) is pastor of Lansing First Southern Baptist Church in Lansing, Kansas, United States of America. Email: nathan.h.gunter@gmail.com. 
time the center of the world's Christian population has migrated. The Church's population nucleus moved slowly west and north for most of the past two millennia, but the explosive growth of the Christian faith in the Global South and the continuing decline of the Church in the West have produced a rapid shift toward the southern hemisphere.

However, even as the Church's demographics have shifted dramatically, concurrent advancements in global technology, communications, and travel have produced an unprecedented scenario in which pastors and theologians from all continents and cultures increasingly find themselves in conversation with one another. While church leaders in southeast Asia and subSaharan Africa grapple with the theological and practical challenges that accompany rapidly growing national churches, they are able to interact with brothers and sisters thousands of miles away. Similarly, professors in the most well-known seminaries in the West now teach and write with the awareness that they will have students and readers whose home cultures and worldviews are far removed from their own. This globalization of the Church has created a unique challenge and opportunity. Namely, how will pastors, denominational leaders, and scholars do theological work locally for an increasingly global church? Hiebert recognized this emerging need for a 'metatheology' in which local bodies of believers could work through the theological challenges unique to their own contexts even as their ongoing conversation with other global Christians serves as an effective check and balance on their work (Hiebert 1994). More recently, Vanhoozer (2006: 125) stated, 'The present moment calls for a <diasporadic systematics〉, for a way of doing theology that acknowledges a <iasporized Christian identity as well as the dispersal of interpretative authority among the nations. To do theology and to read the Bible with diasporadic consciousness is to recognize that one must never be too at home in any one culture'. That is, because the church is both scattered and interconnected in a way never before seen in Christian history, local pastors and theologians must begin to answer questions of spiritual formation, soteriology, ecclesiology, pastoral theology, and other specific theological challenges in ways that are thoroughly biblical, locally attuned, and globally sensible.

Vanhoozer (2006: 112-119) identifies two critical principles for developing theology with diasporadic consciousness. First, the 'canonical principle' affirms the priority and authority of Scripture's portrayal of God's redemptive work in human history through Jesus Christ for this work. The canon of Scripture must be the foundational authority on which all global Christians agree to form our theology. Second, the 'catholic principle' establishes a local church's responsibility to work out theology for its people even as it maintains an awareness of and accountability to the dispersed body of Christ. He explains, 'On the one hand, what the church over time and 
space has always believed provides an important check and balance to new developments. On the other hand, local theologies become great performances when they respond to specific cultural contexts and to new problems in ways that contain lessons for the whole church' (Vanhoozer 2006: 118). By maintaining commitments to these principles, pastors and scholars across cultural divides can find common ground for theological work that will serve local congregations and build up the global Church. This article contributes an initial step toward forging a theology of pastoral leadership that is 'diasporadically conscious', beneficial to the global church while specifically applicable to the local body. For a helpful series of essays exploring the myriad challenges and opportunities related to the task of global theology, Ott \& Nettland's Globalizing Theology (2006) is a valuable resource.

In light of the increasing cross-cultural dialogue among scholars and pastors within a globalized church and a corresponding desire to encourage greater 'diasporadic consciousness' therein, this article presents the biblicaltheological shepherd-leader motif as a primary metaphor for understanding the distinct nature and role of pastoral leadership. The shepherd-leader motif is prominent in the whole of Scripture and portrays a rich and multifaceted form of spiritual leadership. A review of the Old Testament and New Testament depictions of shepherd language reveals a metaphor which is both sufficiently broad to inform the comprehensive scope of leadership functions and narrowly directed toward the particular identity and responsibilities of those entrusted with the holy work of pastoral ministry. The shepherd metaphor's prevalence throughout Scripture allows it to serve as a foundational theme for the development of a rich biblical theology of pastoral leadership. In contrast to models of Christian leadership which purport to be universally applicable (i.e., they are appropriate and useful in business, education, government, family, etc.), Scripture, in general, and the New Testament, in particular, consistently attributes shepherd-leader language to the unique role of pastoring God's people. Thus, the shepherdleader motif emerges as an invaluable metaphor for communicating the biblical standards for pastoral ministry. In this article, I will first present shepherd leadership as a robust metaphor of pastoral leadership by reviewing Scripture's use of the metaphor and recent significant works on the subject. In the second section of the article, I will propose a model profile of the biblical shepherd-leader based upon the insights of the biblicaltheological review. 


\section{Shepherd Leadership}

The shepherd-leader motif in Scripture has garnered increasing attention among scholars concerned with the nature and function of pastoral leadership in recent years. [The research on shepherd leadership presented in this article is published in full length in the author's doctoral thesis (Gunter 2016).] Academic writers have developed exegetical analyses of the shepherding metaphor in biblical theology and surveyed the understanding and practice of shepherd leadership throughout church history (Laniak 2006; Merkle and Schreiner 2014; Tidball 2008; Bailey 2014; Golding 2006a; Golding 2006b). At the same time, both academic and popular writers have endeavored to develop practical guidelines for the practice of shepherd leadership in the modern church (Witmer 2010; Van Yperen 2003; Anderson 1997; Ladipo 1985; Siew 2013; Kinnison 2010). This section of the article will review the biblical depiction of the shepherd leader, giving particular attention to the 'Good Shepherd' discourse in John 10. This is followed by a summary profile of the model biblical shepherd-leader based upon the preceding review of shepherd leadership.

\section{The Good Shepherd as a Pastoral Model}

The shepherd metaphor is an appropriate and useful image for depicting the nature, role, and proper functions of faithful leadership among God's people. A review of recent literature pertaining to shepherd leadership reveals three key themes which will form the remainder of this section. First, the prominence of the shepherding metaphor in both the Old and New Testaments suggests a continuity in the roles and expectations of godly leaders across the epochs of redemptive history. Second, a careful examination of John 10, commonly known as the 'Good Shepherd Discourse', indicates that Jesus' description of the Good Shepherd is rightly understood as a model for future pastoral leaders to emulate. These two biblical observations produce a compelling case for using the shepherd-leader motif as a standard by which to evaluate the practices of shepherd leadership in various global church contexts. The third key theme is set apart as a separate section. This final section will synthesize the insights of major works on shepherd leadership to produce a model profile of the biblical shepherdleader consisting of categories associated with pastoral leadership which may be used by scholars in pastors in various contexts to form a theologically-rooted model for ministry and training.

\section{Prominence of the Shepherd-Leader Motif in Scripture}

The ancient near Eastern shepherd is one of the most frequently invoked images of ideal leadership for God's people found in the Bible. Laniak explains that the shepherd metaphor proves especially useful for depicting 
godly leadership due to the obvious parallels between the multi-faceted roles and responsibilities of the well-known common shepherd and the spiritual leaders of Israel and the church:

Shepherd is a felicitous metaphor for human leadership because both occupations have a comparable variety of diverse tasks that are constantly negotiated... Shepherds had to combine broad competencies in animal husbandry with capacities for scouting, defence, and negotiation. The use of the shepherd metaphor for leaders affirms the coherence and inner logic of these diverse tasks and competencies (Laniak 2006: 40).

Thus, Scripture repeatedly draws upon the shepherding metaphor to describe the leaders of God's people. Bailey asserts that the major portions of Scripture depicting shepherd leadership emerge and build upon each other in such a way that ancient readers readily understood the central significance of the metaphor for the life of God's people (Bailey 2014: 271). If this pattern is indeed embedded in such a way that it was obvious and instructive to ancient believers, then it follows that the metaphor is worth expounding to the modern Church and applying to our understanding of modern spiritual leadership.

Shepherd imagery is found from the earliest chapters of Genesis and soon is established as the central metaphor for describing leadership in ancient Israel. Hamilton states that the key contribution of the shepherd metaphor in the Old Testament is to produce a recognizable pattern for leadership in the New Testament era, a pattern he describes as 'the suffering righteous shepherd' (Hamilton Jr. 2014: 25). He identifies Abel and Abraham as the earliest examples of biblical shepherds whose lives demonstrated faithfulness to God along with difficulty or rejection in the world (Hamilton Jr 2014: 26-27). Later in the Old Testament, Moses and David are recognized as the prototypical shepherd-leaders in Israel's history (Laniak 2006: 75; Bailey 2014: 32; Witmer 2010: 14-20). Laniak traces the development of the shepherd-leader motif into the writings of the Old Testament prophets Isaiah, Jeremiah, Ezekiel, and Zechariah, who used shepherding language to chastise Israel's faithless leaders (Jeremiah 23, Ezekiel 34) and to speak words of comfort and hope to the people (Isaiah 40, Ezekiel 37, Zechariah 13) (Laniak 2006).

The Old Testament utilizes the good shepherd metaphor to convey multiple truths about leadership in Israel. Bailey notes three distinct uses of shepherd imagery in the Old Testament (Bailey 2014: 31-34). First, God describes himself as Israel's true shepherd. Referring to himself as a shepherd underscores both the incomparable goodness of God's care, provision, and protection for his people as well as the degree to which his care ex- 
tends. Witmer explains the unique quality of the shepherd metaphor as it communicates the nature of God's true relationship with his people:

This is one important distinction between the metaphor of father and that of shepherd. Children grow up and become less dependent on their earthly fathers, though the relationship continues. Sheep, on the other hand, are always completely dependent on their shepherd... Therefore, the imagery of shepherdsheep captures the comprehensive sovereignty of the shepherd over the sheep and the need of the sheep to yield completely to his care (Witmer 2010: 13).

Second, the Old Testament refers to Israel's leaders as shepherds. It is worth noting here that Scripture applies shepherd leadership language to both civil and religious leaders in Israel, indicating that God extends the expectations of faithfulness to all spheres of leadership (Laniak 2006). Although Moses and David are presented as models of shepherd leadership to Israel, in time the nation's leaders departed from their precedent of faithful leadership. This leads to Bailey's third observation, the Old Testament ultimately employs shepherd imagery to point to the coming of Christ (Bailey 2014: 32). Thus, the presence of Moses and David as prototypical shepherd leaders had a greater purpose than merely providing an example for future leaders of Israel. 'To use theological language, these figures ‘typologically> anticipate the role of Christ as the ultimate shepherd' (Laniak 2006: 34). The Old Testament introduces, develops, and illustrates the rich shepherdleader motif in order to communicate to Israel the nature of their relationship to God, but the fullness of the good shepherd imagery is not found until the pages of the New Testament.

The shepherding metaphor is not the exclusive description applied to either Christ or pastoral leadership in the New Testament, but it remains prominent and instructive. The shepherd-leader motif is most pronounced in the gospels, especially Matthew and John, where Jesus is portrayed as the Good Shepherd who fulfills the promise of an eschatological shepherd-ruler for the people of Israel (Köstenberger 2014: 57-58; Laniak 2006: 171-172). Schnabel argues that Jesus' understanding of himself as the seeking and saving shepherd promised in Ezekiel 34 is critical to defining his mission of proclaiming and enacting the arrival of God's Kingdom to the sick and the lost (Schnabel 2004: 1.214-216). Paul's letters feature the shepherd metaphor less frequently, although the imagery is not absent. Rather than directly referring to leaders within the church as shepherds, he uses shepherding language to describe the function of faithful elders in the life of the church (Merkle 2014: 63-64; Tidball 2008: 104). Witmer explains:

When called to summarize the work of the elders in these final moving words, he returns to the imagery of shepherding. The elders are to be vigilant in 'watching 
over' (prosecho) not only themselves but also the believers at Ephesus. It is noteworthy that they are described as overseers (episkopous). Calvin observed that 'according to the use of the Scripture, bishops (episkopoi) differ nothing from elders (presbuteroi)'... The action to which both terms point and to which elders and overseers must be committed is 'to shepherd the church of God' (Witmer 2010: 38-39).

Merkle concludes that Paul's use of shepherd language as an imperative for or a descriptor of church leadership indicates that his primary concern was to describe the proper function of leadership rather than its proper title (Merkle 2014: 85). Peter's closing charge to the church's elders draws heavily upon the shepherd language Jesus used to re-instate the leader of the apostles in John 21 (Laniak 2006: 225-234; Tidball 2008: 192-195; Bailey 2014: 263-268). This passage also indicates the temporary and subordinate function of the New Testament elders' shepherding role. Peter's reference to Christ as the chief Shepherd 'implies that the elders who shepherd God's flock are continuing, in part at least, Christ's ministry' (Achtemeier 1996: 329). Other New Testament passages, such as Hebrews 13:12-21 and Revelation 7:17 further reinforce the understanding that Jesus is the 'great shepherd of the sheep' who is the mediator of the New Covenant and continues to lead his flock into eternity (Lane 1991: 562). Thus, the New Testament uses the shepherd metaphor to reveal Jesus' true identity, to describe his relationship to his people, and to describe the role and responsibilities of the church's leaders.

\section{Jesus as the Model Shepherd in John 10}

John's gospel features the most explicit usage of shepherd language in the New Testament. John declares that his gospel is intentionally arranged in such a way as to assist the reader in coming to believe in Jesus (John 20:3031). This insight encourages careful exploration into each passage to better understand exactly how the author portrays Jesus and how this affects his followers. The Good Shepherd discourse (John 10:1-21) is 'an extended and complex parable' in which Jesus draws heavily on Old Testament shepherd-leader language to identify himself as the promised shepherd for whom Israel had been waiting, as well as to sharply contrast himself with the foolish shepherds in Israel in his day (Tidball 2008: 80).

When the Pharisees provoked Jesus by casting out of the synagogue a man who would not deny him, Jesus rebukes these leaders with the parable of the Good Shepherd (Köstenberger 2004: 297; Keener 2003: 1.797; Carson 1991: 379-380; Laniak 2006: 213). Jesus immediately draws a sharp contrast between himself and the Pharisees, identifying himself as the door by whom sheep go in and out safely while he labels the Pharisees 'thieves and robbers' (10:1-9). With these designations, Jesus draws upon the con- 
demnations of Israel's careless shepherds pronounced by the prophets Ezekiel and Jeremiah (Laniak 2006: 210; Köstenberger 2004: 303; Bruce 1983: 223). The prophets' primary criticism of the shepherds in their days' was that Israel's leaders did not care for their people. In contrast, Jesus presents himself as the good shepherd 'who lays down his life for the sheep' (10:11), emphasizing his care for his people. Tidball argues that the central emphasis of this passage is the distinct quality of affection for people found in Jesus which is lacking in Israel's previous leaders:

The burden of John 10, however, is not so much on the task of the shepherd as on the manner in which the shepherd undertakes his role. Unlike the 'false shepherds', the good shepherd has a close and caring relationship with his flock... The climax of the metaphor takes this exercise of courage to the ultimate degree. The shepherd does not put the interests of the sheep first only when it is reasonable to do so, but also when it requires more than might be expected (Tidball 2008: 81-82).

Bruce affirms this assertion, stating, "The sgood shepherd shows himself to be a good shepherd because the welfare of the sheep, not his own, is his primary care' (Bruce 1983: 226). The care that Jesus proclaims (and practically demonstrates through the remainder of John's gospel) is the perfect revelation and fulfillment of the shepherd pronouncements made by the Lord to Israel throughout the Old Testament (Köstenberger 2004: 299-300; Beasley-Murray 1987: 168).

Jesus' self-identification as the good shepherd promised by the Old Testament prophets is a crucial Christological development in John's gospel, but a pressing question demands attention if the standard of this passage is to be applied to pastors. Namely, is the 'Good Shepherd' merely a messianic designation, or is Jesus prescribing a model for future godly leaders to emulate? Several scholars have argued that the shepherd language in John 10 should be rightly understood as prototypical for future shepherds in the church. Much of this argument centers on John's use of the Greek word kalos (good) as the adjective before shepherd. Laniak explains:

Kalos implies an attractive quality, something noble or ideal. 'Model' captures these connotations, but also implies a second nuance that is important in this context: Jesus should be emulated. John makes it clear elsewhere that Jesus is ultimately training his followers to be like him in his life and death (4:34-38; 14:12; $17: 20 ; 20: 21-23 ; 21: 15-19)$. They will eventually take care of his flock and risk their lives like their master (21:15-23) (Laniak 2006: 211).

Carson and Michaels concur that the vocabulary John employs denotes the good shepherd as 'true', 'real', 'genuine', 'noble', or 'ideal', and presents Jesus as 'the very model or prototype of what a shepherd should be' (Car- 
son 1991: 386; Michaels 2010: 585). Additionally, Keener has argued that had John intended to define the good shepherd as absolutely moral or righteous in character, the Greek adjective agathos would have been a more common and appropriate descriptor (Keener 2002: 813).

Expanding on Hamilton's 'suffering righteous shepherd' theme adds another important dimension to describing the unique goodness of Jesus as shepherd in John 10. Hamilton traces the development of this theme throughout the Old Testament from the Patriarchs forward to King David and several key messianic prophecies. He notes that Jesus 'is the ultimate fulfillment of the typological pattern of the suffering righteous shepherd' who recognizes that suffering is a necessary companion to righteousness (Hamilton 2014: 30). Köstenberger links this concept directly to John 10, explaining the Jesus' frequent references to his self-sacrifice in this chapter 'makes this the focal point of the characterization of the sood shepherd' (Köstenberger 2004: 307-308). The emphasis here is not that the shepherd is called 'good' solely because he suffers and dies, but that his goodness is demonstrated by his willing endurance of suffering for the salvation of his sheep. That is, the suffering righteous shepherds suffers for a purpose, for the good of the sheep in his care. Carson explains, 'Moreover, Jesus' death is here presented as a sacrifice peculiarly directed to the redemption of his sheep, whether of this (Jewish) sheep pen or of others (v. 16). This emphasis on the intentionality of Jesus' sacrifice is itself grounded on Jesus' peculiar intimacy with his sheep' (Carson 1991: 386-387).

Other scholars have taken different approaches to explaining the 'good' in the Good Shepherd moniker. For example, Neyrey connects John's use of kalos (which he prefers to translate 'noble') with the Greek concept of a noble, or honorable, death (Neyrey 2001: 287). Others note the sacrificial act of dying as that which marks Jesus as the good shepherd, emphasizing that his one-time sacrifice cannot be duplicated (Clemens 2003: 19; BeaselyMurray 1987: 170). These arguments prove unpersuasive, however, because John uses kalos to describe the shepherd's relationship and care for the sheep in addition to his sacrifice (Neyrey 2001: 268; Carson 1991: 387; Köstenberger 2004: 306; Laniak 2006: 216-217). This suggests that Jesus had in view more than just his sacrificial death when he spoke of the good shepherd, but intended rather to hold up his entire life and ministry as a model.

Finally, the assertion that Jesus intended his description of the good shepherd in John 10 to serve as a model for future leaders is supported by later appearances of shepherd language in John's gospel and the rest of the New Testament. Schnabel suggests that like Jesus, who self-identified as the Good Shepherd who glorified the Father and would lay down his life for his sheep, the disciples received and passed on to the next generation of 
church elders a mission of loving self-sacrifice and an identity as 'envoys of Jesus, in whom God reveals himself to the world' (Schnabel 2004: 379). Tidball notes a direct connection between the charge Jesus gives to Peter to shepherd his people (John 21:15-17) and the discourse in John 10 (Tiball 2008: 84). Peter extended the charge to practice shepherd leadership in the pattern of the Good Shepherd to all of the elders of the church in 1 Peter 5:1-4 (Tiball 2008: 84; Witmer 2010: 34-36). Achtemeier explains, 'In the context of this letter, the immediate derivation of this command is probably to be seen in John 21:16, with Peter here understood as the mediator of that tradition' (Achetemeier 1996: 325). Significantly, Achetemeier further confirms that Peter's exhortations to his fellow elders extend the biblical notion of suffering in righteousness while loving God's people (Achtemeier 1996: 326). The Apostle Paul also appealed to elders to shepherd their churches by enduring tribulation and caring for the flock (Acts 14:22-23; 20:28-32) (Hamilton 2014: 30). This tradition of shepherd leadership as the pattern for church eldership remains to this day.

This section of the article has demonstrated that shepherd language is deeply embedded throughout the Old and New Testaments, providing a consistent metaphor to tie together the whole of Scripture's teaching concerning spiritual leadership. It has further revealed that Jesus understood and identified himself as the promised eschatological shepherd-ruler of Israel, and that the Good Shepherd discourse in John 10 presents Jesus as the model shepherd after whom future church leaders should pattern themselves. The following section explores the question of how pastors are to understand and emulate the shepherding model put forth by Jesus.

\section{Profile of a Shepherd Leader}

The considerable extent of the shepherd-leader motif throughout Scripture provides sufficient insight into the nature and role of spiritual leadership to construct a reasonable profile of a model leader. Multiple recent works on shepherd leadership have identified specific categories for describing shepherd leadership. Through the Center for the Development of Evangelical Leadership, Laniak outlined three critical elements that comprise a biblical shepherd-leader: calling, character, and competence (Laniak 2001). Sills identified a slightly different list of aspects to be included in a holistic approach to equipping indigenous pastors: head, heart, and hands (Sills 2010: 52-62). Combining these two works produces a useful construct for this research. Laniak's elements of character and competence are very similar to Sills' usage of heart and hands. However, because this article explores the nature and function of leadership for those already serving in pastoral ministry, the question of calling will be assumed. Sills' emphasis on the 'head', the knowledge necessary for biblical leadership, is a more appropriate cate- 
gory for this study. Thus, combining the works of Laniak and Sills, and alliterating the terms, produces the following list of critical components for describing the model shepherd leader: content, character, and competence.

It should be noted here that the three-fold construct of this shepherdleader profile-content, character, and competence-is not unique to the works of Laniak and Sills. The categories developed by Laniak and Sills in their respective works provide a useful and representative framework for exploring the holistic nature of biblical depictions of shepherd leadership. Laniak's work, in particular, interacts more deeply with the whole of Scripture in describing the different components of the shepherd-leader's identity and responsibility than any other relevant recent work. Multiple theological and exegetical works from other authors have contributed to the development of this profile. Contributions from several of these are noted in the following pages.

\section{Content}

The first component of the biblical shepherd-leader profile is content. In this article, this refers specifically to the theological curriculum and instruction associated with a pastor's training for ministry. This is a crucial foundational element in the process of equipping pastors. Thompson explains, 'Despite the pressures that often come from the church and society to define the minister's role in pragmatic terms as the maintenance and growth of the institution, the answer to the question of ministerial identity... is a theological one' (Thompson 2006: 11). As pastors and national leaders in various contexts consider their own work and the task of equipping other pastors for local ministry, the need for theological education must be prioritized. Pragmatic considerations are an important aspect of the pastorequipping process, but biblical-theological instruction directs the pastor's attention toward the specific competencies most needed to fulfill his role in a given context. Guder describes this process of designing curriculum specifically to equip pastors for ministry and mission 'theological formation' (Guder 2010: 308).

Several passages develop the biblical emphasis on theological teaching for leaders. In Jeremiah 3, God promises that he will provide shepherds for Israel 'who will feed you with knowledge and understanding (3:15). This promise includes wisdom for discernment and godly living in addition to biblical knowledge. However, it is instructive that the Lord specifically notes knowledge as a defining trait of his shepherds. The most notable examples emerge from the Good Shepherd discourse in John 10. Köstenberger explains that the entire episode is presented 'as a symbolic discourse, in which a given metaphor (here, shepherding) provides the backdrop for extended reflection' (Köstenberger 2004: 297). Those reflecting on this dis- 
course recognize two immediate implications of the shepherd's teaching. First, the Good Shepherd discourse represents one of the most poignant Christological revelations in all of Scripture (Bailey 2014: 271). Beyond this, though, Jesus drew from the shepherd imagery of his discourse in John 10 to extend the task of shepherding to Peter in John 21 (Bailey 2014: 272). This creates a pattern of forming understandings of both theology and spiritual leadership from biblical precedent. Paul, likewise, emphasized the need for theological and doctrinal instruction to developing pastors (2 Timothy 2:2; Titus 1:9). He declared that in his training of the Ephesian elders that he "did not shrink from declaring to you anything that was profitable, and teaching you in public and from house to house, testifying both to Jews and to Greeks of repentance toward God and faith in our Lord Jesus Christ' (Acts 20:20-21). Texts such as these indicate that theological acumen is an indispensable component of the shepherd-leader profile.

Exactly how theological training of pastors should be designed is a matter that has received considerable attention. Sills argues that a historicalgrammatical method is most appropriate for grounding national pastors in the biblical text and discouraging emotional or intuition-driven interpretations (Sills 2010: 53). Van Yperen advocates a relational, trust-based environment as the key to conveying important biblical truth to growing leaders (Van Yperen 2003). Davis adds yet another consideration, suggesting that training for future pastors should be modified according to the particular gifting and skill set each learner possesses (Davis 2014: 325).

The content of theological education is an element which can and should be customized according to specific needs of a given context. That is, the curriculum design and the pedagogical methodologies may be tailored to best serve the needs of local or indigenous leaders. For example, Sills notes that a comprehensive biblical worldview and teaching can be effectively conveyed through oral methodologies to non-literate learners (Sills 2010: 53). In light of the existing concern for contextualized approaches to theological education, this article withholds specific prescriptions for curriculum design and methods of content delivery.

\section{Character}

The second component of the biblical shepherd-leader profile is character. This relates primarily to the development of a pastor's affections for and attitudes toward God, himself, and the people under his care.

Biblically speaking, it may be argued that character is the most emphasized aspect of shepherd leadership. Scripture speaks extensively to the importance of the shepherd's character as revealed in his caring relationship toward the people under his leadership. In Psalm 23, God presents himself as the Shepherd of Israel, repeatedly emphasizing his comprehensive care for the wandering sheep through his gentleness, watchfulness, and provi- 
sion (Bailey 2014: 63-64). Ezekiel 34 includes some of the strongest shepherd language in the Old Testament, but the language in this passage is a harsh condemnation of Israel's rulers. The chief accusation against these leaders was that they had neglected the people in their care. Laniak explains, 'Ezekiel depicts shepherds who show no regard for the obvious needs of the flock, and-especially to the point-they appear oblivious to the expectations inherent in their role as undershepherds. Shepherds were not expected simply to tend a flock; they were serving its owner' (Laniak 2006: 152). God introduces himself as a shepherd by highlighting the unfailing care he has for his people, and later condemns Israel's human shepherds specifically because they cared nothing for the people.

This contrast between the divine Shepherd and Israel's faithless shepherds carries directly into the Good Shepherd discourse in the New Testament (Laniak 2006: 210; Köstenberger 2004: 303; Bruce 1983: 223). Jesus describes his perfect care for his people in terms of his willing sacrifice (10:11, 17-18), his close relationship with the sheep $(10: 14)$, his pursuit of the lost sheep (10:16), and his protection of the sheep (10:9,28). Contrasted against the carelessness of the thieves and robbers who cared little for people, 'This intimacy of a shepherd and his flock provides a beautiful illustration of the trust, familiarity, and bond existing between Jesus and his followers' (Köstenberger 2004: 302). As previously noted, the care that Jesus articulated and modelled in John 10 he later commanded Peter to emulate in his leadership over the church (John 21:15-17). Peter then extended the command to the rest of the church's elders to shepherd their flocks in the same manner (1 Peter 5:2-3).

The shepherd-leader's distinguishing mark of self-sacrificing care for his people is predicated upon an observable individual lifestyle which may be categorized as 'above reproach' (1 Timothy 3:2). Paul's list of qualifications for aspiring elders in 1 Timothy 3:1-7 is predominantly concerned with matters of personal character and integrity. Mounce describes the error of the Ephesian elders and Paul's instructions to Timothy to address the situation in this way: "Not only was their theology erroneous, but their behavior was reprehensible... Timothy must be sure that they exhibit a high degree of moral fiber; they must be above reproach' (Mounce 2000: 184). Mounce further explains that the lists of characteristics in the Pastoral Epistles should be viewed as official, even if the ad hoc nature of the lists suggest they are not exhaustive (Mounce 200: 184). Thus, a character marked by integrity and personal holiness is a non-negotiable component of the biblical shepherd-leader profile.

While character that is above reproach is prerequisite to leadership as an elder in the local church, it is clear that a pastor's passionate care for the people in his flock is the distinguishing mark of shepherd leadership in 
Scripture. Yet the ways that care is expressed may vary according to the culture in which a pastor serves. Again, it is incumbent upon local pastors and leaders to grasp Scripture's portrayal of the shepherd's character and translate this into the cultures and contexts in which they serve.

\section{Competence}

The third component of the biblical shepherd profile is competence. This aspect of the profile explores exactly how a pastor exercises shepherd leadership and which related skills are necessary for ministry. Competence is the most practical of the three, and in many regards may be the most compelling to action-oriented Western researchers. However, the interests of this article are the biblical-theological depictions of this trait, not the specifics of how specific competencies are demonstrated in a particular context.

While the Bible consistently highlights matters of character as being of primary importance in portraying shepherd leadership, it provides multiple examples of practical competencies that godly leaders are expected to possess (Laniak 2001). These abilities are not necessarily restricted to spiritual leadership, but may include administrative, governing, or even military leadership as well (Laniak 2006: 22). The Psalms depict the Lord as a good shepherd who skillfully cares for his sheep by leading them through the dangerous wilderness (78:52), protecting and sheltering them (18:1-3), and providing sustenance and rest (23:1-2) (Bailey 2014: 31-65). Moses and David, as prototypes of the shepherd-leader, modeled several competencies that are associated with the role. In Deuteronomy 18:15, Moses predicted that the Lord would raise up another prophet within Israel who would speak the word of God to the people (Hamilton 2014: 28). While this text refers ultimately to the coming of Jesus, this prediction established a pattern of Old Testament shepherds declaring the word of the Lord. In the New Testament, the ability to teach is the only practical skill listed among the qualifications for church elders in 1 Timothy 3. David is described as a shepherd-ruler over Israel who 'guided them with his skillful hand' (Ps 78:72). In 1 Samuel 16, David is introduced as a young shepherd who already possesses the skills of soothing disturbed sheep (musicianship) and physically protecting the sheep from outside threats (Laniak 2006: 98-99). Looking again to John 10, the practical work of the Good Shepherd is observed in calling his sheep by name and leading them in and out of the pen (4), saving his sheep from thieves and robbers (8-9), laying down his life for the sheep (11), knowing his sheep in close relationship (14-15), and pursuing sheep who are separated from the flock (16). Additionally, the list of qualifications for elders contained in the Pastoral Epistles, while predominantly concerned with personal character, also note that a pastor must be skilled both in teaching and in oversight (Mounce 2000: 159). This is not an 
exhaustive list of the shepherding acts observed in the Bible, but it is sufficient to demonstrate the general spectrum of shepherding responsibilities.

Multiple writers have attempted to summarize and categorize the practical competencies associated with biblical descriptions of shepherd leadership. Reviewing the roles of Moses and David as human representatives of God's care for Israel, Laniak summarized their key shepherding tasks as protection, provision, and guidance (Laniak 2006). Golding includes each of these roles and adds the responsibilities of gathering sheep who are either lost or scattered (Golding 2006a: 22). Witmer's 'Matrix for Ministry' presents the shepherd's primary responsibilities as knowing, feeding, leading, and protecting the sheep (Witmer 2010: 107-192). Tidball develops a more specific task list to describe the practical work of shepherd-leaders. He writes:

We are called to accompany many who walk through the spiritual wastelands of their lives, guiding them, feeding, and protecting them. We are called to

- seek out those who cannot find their way and bring them into the safety of the fold

- go after those meandering away and restore them

- take up the wounded victims and minister healing

- instruct the ignorant and the young so they can grow in strength

- exercise the discipline on those whose presence is detrimental to the flock (Tidball 2008: 84-85).

Finally, Davis offers the most comprehensive profile of the shepherd leader among sources consulted in this review. His list encompasses all three critical components identified here-content, character, and competence. In addition to the tasks noted by others, he specifically calls for shepherd leaders who will exercise patience in instigating needed change within a flock, model faithfulness before the flock, intentionally develop other shepherd leaders for the flock, intercede for the sheep in prayer, and evaluate the ongoing ministry of the church (Davis 2014: 313-334).

Simply compiling all of the roles and responsibilities identified by these works into a single task list for the shepherd leadership would produce a list of core competencies which, while it is not an exhaustive list of shepherd tasks, is nevertheless overly extensive and unwieldy. Thus, for the purposes of this profile, the general categories of shepherding competencies is drawn from a combination of Laniak's and Golding's lists, including-protection, provision, guidance, and gathering of the sheep. As with the previous components included in this profile, each of these elements of competency may 
be manifested differently in various contexts. As pastors and theologians work out appropriate local methods of practicing protection, provision, guidance, and gathering, local churches will be served well. Additionally, communicating the process by which local leaders determine their unique practices of shepherd leadership will enable believers in different locales to see Scripture more clearly illuminated.

\section{Toward Biblical Shepherd Leadership}

The rapid global growth and globalization of the Church have produced a unique opportunity for pastors and theologians around the world to collaborate in the work of theology. Never before has such a large and diverse group of theologians had access to biblical materials, theological and historical works, and one another in the manner that is seen today. Specifically, pastors and theologians in the Global South are increasingly shaping the work of theology. Sills explains, 'Our understanding of Christianity has been defined by the Western church's theological contributions, but as the church in the south and east grows, so will its influence in shaping our understanding of theology and the world's understanding of what it means to be Christian' (Sills 2015: 189). The growing voice of a diverse set of pastors and theologians around the globe is a welcome development. With a shared commitment to the principles of canonicity and catholicity (Vanhoozer 2006:112-119), Christian leaders can work across cultural divides to produce theology that is informed by the insights of Christians from different times and cultures while being applied to the particular needs of differing local contexts.

This article presented the biblical-theological shepherd-leader motif as a primary metaphor for understanding the distinct nature and role of pastoral leadership. I contend that this metaphor, as revealed in Scripture, is comprehensible and transferrable across cultures and languages. As theologians seek to develop theologies which are 'diasporadically conscious'tailored to local needs while remaining biblically faithful and globally accountable-the shepherd-leader motif represents a case study in biblical pastoral leadership. The model shepherd-leader profile presented in this article identifies biblical categories of emphasis in pastoral leadership with the intention of fostering further scholarship and dialogue among global theologians whose contributions will further enhance our grasp of the identity and task of shepherding God's people.

\section{Bibliography}

Achtemeier PJ (1996) 1 Peter: A Commentary on First Peter. Minneapolis, MN: Fortress Press. 
Anderson L (1997) They Smell Like Sheep: Spiritual Leadership for the 21st Century. West Monroe, LA: Howard Publishing.

Bailey KE (2014) The Good Shepherd: A Thousand-Year Journey from Psalm 23 to the New Testament. Downers Grove, IL: IVP Academic.

Beasley-Murray GR (1987) John. Waco, TX: Word Books.

Bruce FF (1983) The Gospel of John: Introduction, Exposition, and Notes. Grand Rapids, MI: William B. Eerdmans.

Carson DA (1991) The Gospel According to John. Grand Rapids, MI: William B. Eerdmans.

Clemens T (2003) Searching for the Good Shepherd. Nederlands Archief voor Kerkgeschiedenis 83(1): 11-54.

Davis AM (2014) Leading the Church in Today's World: What It Means Practically to Shepherd God's Flock. In Merkle BL \& Schreiner TR (eds) Shepherding God's Flock: Biblical Leadership in the New Testament and Beyond. Grand Rapids, MI: Kregel Minsistry. Pages 309-334.

Golding TA (2006a) The Imagery of Shepherding in the Bible Part 1. Bibliotheca Sacra 163(649): 18-28.

Golding TA (2006b) The Imagery of Shepherding in the Bible Part 2. Bibliotheca Sacra 163(650): 158-175.

Guder DL (2010) Theological Formation for Mission Practice. In Mortenson V \& Nielsen AO (eds) Walk Humbly with the Lord: Church and Mission Engaging Plurality. Grand Rapids, MI: William B. Eerdmans.

Gunter NH (2016) Mission Agency Methods for Equipping Pastors as Shepherd Leaders. EdD Thesis. The Southern Baptist Theological Seminary, Louisville, $\mathrm{KY}$.

Hamilton JM (2014) Did the Church Borrow Leadership Structures from the Old Testament or Synagogue? In Merkle BL \& Schreiner TR (eds) Shepherding God's Flock: Biblical Leadership in the New Testament and Beyond. Grand Rapids, MI: Kregel Ministry.

Harris MJ (1999) Slave of Christ: A New Testament Metaphor for Total Devotion to Christ. Downers Grove, IL: InterVarsity.

Hiebert PG (1994) Metatheology: The Step beyond Contextualization. Anthropological Reflections on Missiological Issues. Grand Rapids, IL: Baker. Pages 93-103.

Howell Jr DN (2003) Servants of the Servant: A Biblical Theology of Leadership. Eugene, OR: Wipf \& Stock Publishers.

Keener CS (2002) The Gospel of John: A Commentary. Peabody, MA: Hendrickson Publishers.

Kinnison QP (2010) Shepherd or One of the Sheep: Revisiting the Biblical Metaphor of the Pastorate. Journal of Religious Leadership 9(1): 59-91.

Köstenberger AJ (2004) John. Grand Rapids, MI: Baker Academic. 
Köstenberger AJ (2014) Shepherds and Shepherding in the Gospel. In Merkle BL \& Schreiner TR (eds) Shepherding God's Flock: Biblical Leadership in the New Testament and Beyond. Grand Rapids, MI: Kregel Ministry.

Ladipo Y (1985) Shepherding: the Hallmark of a Christian leader. East Africa Journal of Evangelical Theology 4(2): 10-14.

Lane WL (1991) Hebrews 9-17. Dallas, TX: Word Books.

Laniak TS (2001) Shepherds after My Own Heart: A Survey of Biblical Leadership. In Leadership in the 21st Century. Center for the Development of Evangelical Leadership.

Laniak TS (2006) Shepherds after My Own Heart: Pastoral Traditions and Leadership in the Bible. Downers Grove, IL: InterVarsity Press.

Lewis PV (1996) Transformational Leadership: A New Model for Total Church Involvement. Nashville, TN: Broadman \& Holman.

Malphurs A (2003) Being Leaders: The Nature of Authentic Christian Leadership. Grand Rapids, MI: Baker Books.

Merkle BL (2014) The Pattern of Leadership in Acts and Paul's Letters to the Churches. In Merkle BL \& Schreiner TR (eds) Shepherding God's Flock: Biblical Leadership in the New Testament and Beyond. Grand Rapids, MI: Kregel Ministry.

Merkle BL, Schreiner TR (2014) Shepherding God's Flock: Biblical Leadership in the New Testament and Beyond. Grand Rapids, MI: Kregel Ministry.

Michaels JR (2010) The Gospel of John. Grand Rapids, MI: William B. Eerdman's Publishing Company.

Mounce WD (2000) Pastoral Epistles. Nashville: Thomas Nelson Publishers.

Ott C, Netland HA (eds) (2006) Globalizing Theology: Belief and Practice in an Era of World Christianity. Grand Rapids, MI: Baker Academic.

Neyrey JH (2001) The 'Noble Shepherd' in John 10: Cultural and Rhetorical Background. Journal of Biblical Literature 120(2): 267-291.

Parratt J (ed) (2004) An Introduction to Third World Theologies. Cambridge: Cambridge University Press.

Schnabel EJ (2004) Early Christian Mission. Downers Grove, IL: InterVarsity Press.

Siew Y (2013) Pastor as Shepherd-teacher: Insiders' Stories of Pastoral and Educational Imagination. Christian Education Journal 10(1): 48-70.

Sills MD (2015) Changing World, Unchanging Mission: Responding to Global Challenges, Downers Grove, IL: IVP Books.

Sills, MD (2010) Reaching and Teaching: A Call to Great Commission Obedience. Chicago, IL: Moody Publishers.

Thompson JW (2006) Pastoral Ministry according to Paul: A Biblical Vision. Grand Rapids, MI: Baker Academic.

Tidball D (2008) Ministry by the Book: New Testament Patterns for Pastoral Leadership. Downers Grove, IL: IVP Academic. 
Vanhoozer KJ (2006) 'One Rule to Rule Them All?' Theological Method in an Era of World Christianity. In Globalizing Theology: Belief and Practice in an Era of World Christianity. Grand Rapids, MI: Baker Academic. Pages 85-126.

Van Yperen J (2003) The Shepherd Leader. St. Charles, IL: ChurchSmart Resources.

Witmer TZ (2010) The Shepherd Leader: Achieving Effective Shepherding in Your Church. Phillipsburg, NJ: P\&R Publishing. 